\title{
A Fighting Battle
}

\section{A Prisoner's Wife}

Since the early 1970s thousands, of women have trekked to jails for visits week in, week out, year in, year out. With their partners serving lengthy sentences, they have had to struggle on their own, often in dire circumstances. Here is one woman's story, but it is typical of many.

Marie (not her real name) was still a teenager when she was married in 1973. Within a few years, her husband was arrested and she was left to raise a young daughter by herself for the next six years. Her husband's release heralded but abrief period of married life together; two years later, he was arrested again and sentenced to an even longer term of imprisonment. Marie was then pregnant with her second child. By the time of his eventual release, they will be twenty years married; fourteen of these, Marie will have spent on her own.

With courage and honesty, Marie speaks of her life - the loneliness and doubts, the hardship and struggle to keep her family together. She talks candidly of the strains in the relationship with her husband, and of the unrealistic expectations imposed by people in the republican and the wider community. Marie's experience reflects the reality for many partners of prisoners.

How did your life change after your husband's arrest, both the first and second time?

The first time he went into prison in 1977, I thought my whole world had fallen in; it was like a death, I was in mourning for a long time. I had to listen to his family going on about 'our poor Sean' but what about me? I had my daughter Orla to bring up, no money, and I was running up every week to see him. At times I used to say, 'I wish I was dead, I can't handle it,' but I always put on a front, it was really hard. Then I had to be both a mother and father to my daughter and try to explain to her why her father was in jail. I just never thought he'd end up in prison, I'd just blocked it out of my mind.

If my daughter was sick, I had to sit up with her and make all the decisions too. I felt very lonely many a night and I was on my own, and to me, both our families didn't understand one bit how I felt; I was doing time just as much as my husband but they would say to me, 'You have your freedom.' Oh I used to hate him and them at times! Then there were nights when you felt like having sex. You had to put that to the back of your mind, but I know I must have been hard to stick as I felt I was missing out on a lot of things my personality would change. Then I got a wee job and it made life a bit easier but I still had to put up parcels, clothe him, and put money in for his tuckshop. 
The second time, he was arrested in 1985. It was hard, but not as hard to accept, as always in the back of my mind I knew he could land in jail again. I knew I had to be strong as I was pregnant again and on my own. The two years he was out he was my husband, lover, and best friend all rolled into one, and it was hard to take in that he was away. Still, I had days when I didn't care about him. I would say to myself ,'That's it, I'm not going up to see him any more, I don'tcare what the families say.' The first time around you would stay by your husband and even your mother would say things like, 'you have to stick by him,' now I wouldn't listen and if I wanted to leave him I would and nobody would stop me. They still don't know what it's like. 'Good old Marie, she stuck by her husband' but it was a fighting battle I know I've overcome as the years have gone by.

It is hard to explain how I felt when I went into hospital to have Liam, our second child. It was great when it was over. Me and the baby was perfect, but then I used to see the other women's husbands or boyfriends in visiting and I'd have mixed feelings - I'd love and hate my husband at the same time. I didn't stay long in hospital, I asked to get out early. When I walked into my house, there was nobody there, only Orla; my sister was with me and I just felt like screaming out of me, 'Will someone help me!' Oh they all helped, but still didn't understand the lonely feelings I had and I felt as if no one cared. I know it was my fault, I never would say anything; maybe if I had, they might have understood a bit more.

I always had to get someone to look after the baby when I was going up on visits. Thank God this time around I was near his mother and she watched the child all the time. I can't thank her enough. It got to the stage for a while that I didn't want to go up to the prison, but I never said. I had to get up very early those mornings, about 6:30, get Liam ready and in a good mood, then take him down to his granny's. But then I'd an older child too, I had to think of her. Although she was a great help too, she was like a wee mother to the baby, I don't know how I would've managed without her.

It took me a long time to get used to him out of the house. Every day around teatime, he would have come in for his dinner, and if I heard the door open around that time I would say to myself, 'That's Sean,' and if I was making the dinner, I would forget and put a plate out for him. Sometimes out in the kitchen, I would look at the clock, if it was the time he used to come home I used to have tears in my eyes knowing he wasn't coming. It hurt very bad.

\section{How did jail affect your relationship? Did/does it cause problems?}

It does cause problems and you have to work at the relationship. When I was younger, going up to see him the first time he was in, I took it for granted - we were married and I didn't need to work at the relationship. Then later on, when I got the wee job in the bar, I noticed things were changing between us, he would ask more questions like, 'Does anyone tap on you? Do you miss sex a lot?' At the time I just said, 'No' to keep him happy, not that anyone did tap me up 
anyway but I did miss sex now and again. If any fella in the bar had said to me, 'You're looking well tonight, Marie,' I wouldn't have told my husband as I knew he would've taken it the wrong way; but, it made me feel good all the same, it made me feel I was a woman. At the time, I felt I was put under pressure and he didn't trust me enough. Anyway, even if I had wanted to, how could I get up to much? All his friends either drank or worked in the bar (a republican bar) so if I'd put a foot wrong he'd have been told right away. It used to get on my nerves that, their eyes were always on you. Sometimes on the visits, we'd be talking and he'd tell me he'd never be in jail again, that he loved me. Most times I believed him; other times I'd say to myself that he's just saying all that to keep me coming up to see him. In those days, we couldn't talk to each other very openly; we were still close and I knew he was worth waiting for but, yes, sometimes he did take me for granted. I always held back too in my letters if I was down, I never told him. I remember one time someone on the bus going to the jail talking about some other girl. She was saying the girl's husband had told her own husband, 'My wife's always moaning about something and is always down.' Guess what the person says? 'Do you not think her poor husband, locked up and all, has enough on his plate? She shouldn't be telling him things like that.' That stuck in my head, that's the way it was with some people.

The second time, I knew what to look out for and I wasn't going to be taken in by him. Now don't get me wrong: he didn't hold me down and I didn't run up to jail because I felt sorry for him. I wanted our marriage to last and I love him. But I noticed myself he'd changed and was thinking of me more and he trusted me more too, I think. As the years rolled by, we started to talk more and more openly with one another and the relationship between us was blooming. I felt great. Now a few times we'd talk about sex. Yes, I do miss sex, but he knows I'm not going to run out and try and pick someone up -no way! There's times months would go by without me even thinking about sex, then maybe something on the TV would make you think about it and I would say to myself, 'Is Sean worth all this? I have to go without a lot of things.' It is a fighting battle at times but thank God I've got to a stage where it doesn't bother me any more. Oh I think about sex still now and again, but I don't question myself any more. I can wait till he comes home.

With the kids you have to work and try and build a good relationship with them and their father. I would talk to them all the time, when they were young, about their father and still do with Liam, the youngest one. I'd buy wee presents and say, 'They're from your daddy.' I remember saying to Liam, 'That's your daddy, say hello when you see him and give him a big kiss.' Sometimes, there were problems when they were up on visits, maybe not taking him on enough and I'd be saying things like, 'That's the way kids go on.' But sometimes, I knew he'd be hurt if they didn't want to sit on his knee or give him a kiss, children don't understand those things. Nowadays, they're bigger and it's far easier, they all get on great. To me, we had to work on everything through the 
years to get the way we are now in our relationship. I hope I don't upset Sean in some of the things I say here, but I know we are very close now and it feels wonderful.

What do prisoners or people in your community expect of a prisoner's wife? Does this extend to her behaviour?

Well, I'm not really sure how to answer that but I'll start with the prisoners. I think that a prisoner takes his wife or his family for granted at times. They listen to what he says but he mightn't listen too much to what they are saying to him at times. Say there's a march coming up, you would have to go 'cause that's what he wants you to do. It's expected of you. Now I'm not saying I go just because of that, I go because I want to go as well. A prisoner's wife is supposed to go up every week to see her husband and stand by him; we're supposed to hold the family together and have no social life, we're supposed to be strong.

Now the second bit of that question is nearly the same as the first. It's like if you go out to a bar you are allowed to drink but not to get drunk, or if you go up to dance everyone is looking at you. I remember when I worked in the bar, I would only dance with fellas who were friends of my husband so people wouldn't talk. If you did go out with a few friends and were enjoying yourself, people would look at you. You're supposed to sit there nice and quiet and not make any noise. Every time you'd move you'd see the eyes following you. Do people think that a prisoner's wife is only out for one thing, sex, just because her husband is in jail! We have rights too. We are just like other wives who go out for the night to enjoy themselves; but, because you're married to an IRA man, his friends and everyone else expect too much. As I said before, you stand by your husband, go up and visit him, and yet you're not supposed to show any feelings that it's getting to you. At times, I feel mad, they wouldn't even ask how you are keeping, it's always ,'How is he?' At times, I would say, 'Sure, he's a well-kept man.'

I know both families look at me at times and say I'm a great mother and all that, but I'm supposed to be like that. I wondered at times if I were ever to say that I'm not going up to see him any more, what they'd say then. I think it would hurt them very bad. But as I said before, I've changed too; I don't let anyone stop me from doing what I want to do. After all, it's my life not theirs. Before, if anything happened with the children or if one of our parents were sick, it was all, 'Don't tell Sean, it'll upset him.' Big deal! It upsets me as well! They would say that he's noone to turn to, but they forget: who have I to turn to? Sure, hardly anyone visits me, so I've to bottle up my feelings.

Do you think that you' re treated/viewed as a prisoner's wife or as a person in your own right? Does this change in different circumstances?

I think I get treated mostly in my own right; but, then I don't be out and about very much to meet different people. Right enough, I noticed when I started training again with my friend Anne last year and we went down to the leisure 
centre and we met these other girls whoknew Anne. Well, they must have heard me saying to Anne that I was up seeing Sean (they never asked me or I'd have been proud to tell them) so they found out that Sean was inside, and when they talked to me there was pity in their voices. So it does change in different circumstances. If you're in company and you're talking away, you'd see their faces change when I mention Sean's in jail. To tell you the truth it doesn't bother me.

What I notice too is if there's any bother in the families or if somebody wanted to find out something, they would come and ask me could I help. They'd think, because Sean's inside, that I could do something. Then you get the people who look upon you as if you're a god. 'Look at her, isn't she great, she's a prisoner's wife.' I know too that some people, even those I know, would look at my kids to see if I dress them nice. They think, just because Sean's not here, I should be down and out, that's why I make it my business to keep the kids and the house nice. I know myself there are other prisoners' wives who just can't manage it all but they would do their best.

To me, I'm the same person I was before Sean went inside again but some people look at you and make excuses just 'cause he's in jail. What I mean is, say I don't wash my hair and run up the town for something, well someone would see you and say, 'Sure, her man's inside.' A girl I know said, 'You've lost a lot of weight,' but I was always thin. Or if I get my hair cut they'd say, 'You're looking great.' All I did is get my hair cut. So what I'm trying to say is people make excuses 'cause your husband is in jail. It's the way they must expect you to be, sorta down and out.

Earlier you said you felt that you'd missed out on a lot of things, that it changed your personality. In what ways and why do you think it changed you?

Well, it boils down to jealousy. Even with our Orla and her fella I'd see them really happy together, sitting on the sofa holding hands and all lovey dovey, and I'd be a bit cranky and get on to her now and again. It's just that I feel that we've missed out on a lot: us growing up together, being able to hold hands, or make love whenever we'd want to. Our life seems to be put on hold all the time. Times I was mad at him on the visits, we'd be kissing and we still couldn't be at ease. That's a few years back. Now it's better because I can handle it better and I can understand my own feelings more too.

When I did work in the bar, I'd see a lot of couples having a good time and I'd wish I could too. But, I knew I couldn't as after all, I was married to Sean and wanted our marriage to work. Don't get me wrong: it wasn't always easy and maybe for a few seconds I'd say to myself ,'To hell with him, I'm going out to enjoy myself' and I'd hate him at the time. It was always a fighting battle between me and my conscience. I'd see a fella looking at me and maybe I'd even flirt a bit but in my mind, that was all. It just made me feel good. Even now there's a bar we go to and I always try to look my best, even a bit sexy as there's no harm in that. But, I think I must have a sign on the back of my head 
Joumal of Prisoners on Prisons, Vol. 7, No. 1, 1996.

that says, 'Look and Don't Touch' as no one (and I mean no one) would try or ever has tried to tap me up.

What I do miss very much is Sean sitting beside me, just his arms around me, holding me tight, making me feel I'm wanted - that's what hurts most. Thank God I don't think I'm as bad now, you get used to not having sex. But one thing I have noticed about myself is that I've got hard on the outside, you build a wall around yourself so you can't get hurt. I dare say, I've given people the wrong impression of myself in the past. I think that's when my personality changed. Sometimes you hate to see others just so happy but I've come a long way now, as people would say, 'She's a big girl now.' That's true. I'm a big girl now and I can understand myself better.

Your life has been a battle. Why did you keep going and not give up?

The way I look at it is the day I married Sean, I had a small battle on my hands. What I mean is Sean was on the run, I was having a baby, and we'd no money, no nothing. It wasn't a good start, but I was happy. I think both our parents had their doubts if the marriage would last. Then Orla came along and there was me trying to be a mother, a wife, and a housekeeper as well but it didn't bother me. It was something you had to do. Looking back now it was a battle to survive. Then, as I said before, Sean being inside was a battle on its own keeping a family going and together, going up on visits, and keeping a good relationship between us. Then there was the battle because you were cut off from sex. You'd be fighting against your own conscience asking, 'Is he worth it?' And there was showing both parents I can do this, keep my family together and try and manage on the money I had. I think if I had a wee bit more money, life would be a bit better.

As for keeping going, I kept going because I had to and I wanted to. I wanted to keep my family together but the big thing was did I love Sean enough to go through all these years waiting on him. The answer is yes, I did love him, and as the years were passing, that love was growing. Then Sean was never a bad person. He was always good to me and Orla and he was a good husband, father, and lover. What I mean is he cared for me and took my feelings in as well. I know we've had our ups and down but who hasn't had? So if I was having any doubts, they would last for a few seconds only as all the good points would come back into my head.

When we were just married, I noticed Sean was out looking for a job or anything to make things easier and everything he did was for me and Orla. In my eyes he seemed so strong. I kept going because I didn't want to throw everything we had out the window. Let me tell you, I thought of giving up a few times. I was just that mad at him leaving me for a second time; then too I was scared myself. I didn't know if I could wait it out or not. It's like an illness. At the start, you're a bit ill, then in the middle it gets worse, and now I feel stronger and it's getting better. Does that make any sense? 
If the roles were reversed, you in jail and your husband outside, would the marriage have lasted?

No I don't think so. Men want sex more, it's more, it's more important to them, and I think Sean would be the same after a while. Ach, I think he' $d$ try his best but it wouldn't last and he'd give in. Then too, people would say, 'Sure, it's only natural as his wife's in jail,' but if it was me or any prisoner's wife, they'd be going out and running you down as no good. That's the way people are. They make excuses for a man flying his kite, but if a woman does it, she's a tramp and no good. It's not right but I don't think it'll ever really change. But it's just not right anyway.

Finally, what are your hopes for the future?

Well, just to be happy. What I mean is I would be daydreaming, having a picture of us sitting in the living room just watching TV but we're all there. Sean out working, coming in home, although I know rightly he might not get a job, but just knowing we are happy, and to be loved. What I miss most too is we mightn't have any more children. Christmas is great having the children around. I know we've both missed out, Sean not being there to see the kids growing up or opening their presents on Christmas morning or their birthdays. But that is all behind us and I believe him this time that me and the kids come first. To tell you the truth, I can't wait. I don't really look into the future too much. The way I feel now is I'm just waiting for Sean to come home, that's my future. 